\title{
USING BIG BOOKS TO PROMOTE THE ELEMENTARY SCHOOL STUDENTS' PARTICIPATION IN ENGLISH CLASSES
}

\author{
Elly Rosalina Susanti \\ English Department, Faculty of Letters, Universitas Negeri Malang, Jl. Semarang 5 Malang 65145, \\ Indonesia \\ (ellyrosalina81@gmail.com)
}

\begin{abstract}
Maintaining the students' participation in the classroom is one of the greatest challenges faced by the English teachers especially those dealing with young learners'. This research aims to find out how well big books can improve the participation of fifthgrade students of SDN Pejagan 1 Bangkalan. Classroom action research was used as the research design. This research consisted of two cycles each of which was conducted in six meetings. The data was obtained from the observation and acting steps then analyzed descriptively. The researcher collaborated with the English teacher to conduct the research. To know the students' opinions towards the use of big books, the questionnaires were given at the end of each cycle. The interview was also done to some students and the English teacher related to the use of Big Book. This research revealed that big book which was big enough so it could be seen by the whole class; has interesting story and character and has eye-catching pictures could effectively encourage the students to participate actively in the English classes. Using big books in the classroom created a non-threatening atmosphere so that the students could express their opinion and disagreement freely.
\end{abstract}

Keywords: Big Book; Students' Participation

First Received:

Final Proof Received:

(July 21, 2020)

(September 15, 2020)

\section{INTRODUCTION}

Two-way interaction between students and teacher is crucial to create a meaningful and conducive classroom environment. An effective learning process occurred when both teacher and students interact and actively participate in the learning activities(Mahbob, 2012). However, maintaining the students' participation in the classroom is one of the greatest challenges faced by the English teachers dealing with young learners since teaching a foreign language to young learners in this case elementary school students is obviously in contrast to teaching adults or adolescents. They are often more enthusiastic and lively as learners. Thus, they will involve in an activity even when they don't quite understand why or how. However, they also lose interest more quickly and are less able to keep themselves motivated on tasks they find difficult (Cameron, 2001).

Low students' participation in English class is one of the problems in SDN Pejagan 1, one of the elementary schools in Bangkalan regency, East Java. Based on the preliminary study, students' active participation in SDN Pejagan 1 Bangkalan especially in the fifth grade was still low. Only three out of thirty-eight students who frequently participated 
while the others participated only when the teacher forced them to answer the questions. When the teacher was explaining the lesson, most of them were noisy, talking to each other. This fact was mainly caused by the monotonous way of teaching English to the students. The English teacher frequently used taking notes and memorizing to teach English to the students. Doing written exercises in the workbook was the activity to check the students' comprehension. She sometimes used English songs in the textbook, but she confessed that she never used any kind of media which could attract the students' interest in the lesson due to her lack of knowledge.

Dealing with this problem, the researcher and the teacher collaborated to create an interactive learning activity so that the students were interested in the lesson and then participated actively in it. Previously, some research related to the use of big books for young learners had been carried out. Nambia (1991) concluded that big books were not only effective to teach various reading strategies and concepts about print but also gave them a meaningful and interesting way of learning English. Big books are also widely used in New Zealand to teach reading. Tse and Nicholson (2014) conducted a research to improve the literacy achievement of lower socioeconomic status (SES) children by combining explicit phonics with big book reading. They claimed that big book reading combined with explicit phonics successfully improved the children's ability in reading comprehension, spelling, and phoneme awareness.

In Indonesia, some research on the use of big books to improve the elementary school students' vocabulary has been conducted widely (e.g.(F. Fahmi, 2015)(Wijayanti, Padmadewi, \& Mahayanti, 2017)and (Indrasari, Novita, \& Megawati, 2018)). However, research which focuses on the use of big book to promote the elementary school students' participation is rarely investigated. (F. Fahmi, 2015) and (Wijayanti et al., 2017) conducted classroom research on the use of big book as media to improve the elementary school students' reading comprehension. Besides, (Indrasari et al., 2018) carried out experimental research to prove the effect on big book using to the elementary school students' vocabulary.

Most of the previous studies mostly focused on using big books to see the impact of big books on the students' language skills and features such as reading and vocabulary. However, learning English is not only about language skills and features. Learning where two-way interaction is encouraged will stimulate learning and makes both the instructor and students feel satisfied, which eventually leads to an effective learning process (Mahbob, 2012). Therefore, this research was addressed to fill the gap. In this present research, Big Books were used to promote the fifth-grade students' participation in SDN Pejagan 1 Bangkalan in the academic year 2018/2019. The results of this research hopefully could help other English teachers who had problems in improving their students' low active participation in English class. 


\section{LITERATURE REVIEW}

The definition of classroom participation varies according to different learning or teaching styles employed. Hence, classroom behaviors such as asking or answering queries would frequently be associated with the definitions of participation in the classroom (Mustapha, Rahman, \& Yunus, 2010). In addition, (Sayadi, 2007) states that verbal or oral participation refers to behaviors of speaking or giving opinions in the classroom, answering and asking questions or comments, and taking part in the classroom discussions. Students who do not take the initiative to actively involve are usually considered as passive. In contrast, nonverbal participation is associated with behavioral responses during the class, including node their head, raise their hands, body movements, and eye contact (Sayadi, 2007). A study conducted by (Mustapha et al., 2010)) which aims to examine the influence of factors that make the participation of undergraduate students in Malaysia found that the attitudes shown by the teachers play an important role in providing incentives for students to participate in class discussions.

Thus, it can be concluded that teachers have a vital role to minimize the boredom in learning English so that the students actively participate in the classroom. Therefore, they should find the appropriate technique and media which can actively engage the students in and promote their active participation during the activity. Among the available techniques of teaching a foreign language, shared reading using big books that combine pictures and stories can be used to promote the students' participation in English classes (Yacoob \& Pinter, 2008).

The term big books describe large format books with big print texts and illustrations that are highly visible to the students as their teachers read them to the entire class. Its size is usually about 18 to 20 inches tall and the print is at least an inch high. The size and clarity of the print and illustrations help to ensure that all the children in the class are able to focus on the book from a distance of at least 15 feet (Nambiar). In addition, big books have some characteristics such as its content and big pictures are easily attract the students' interest, the story has a simple and interesting storyline, it contains rhyme pattern and repeated phrases that the students can learn (Hall \& O' Connor, 2006)

Using big books in the classroom usually involves a shared-reading experience. Shared reading refers to a teacher-centered activity with the teacher pointing to and reading a big book or other enlarged text visible to students in the classroom or in a small group, followed by inviting the students to participate as they feel able to do so (S.C. Hall \& O' Connor, 2006). In addition, (Yacoob \& Pinter, 2008) states that the use of the big book in language learning fosters students' interest and participation. They contribute to the discussion and spontaneously comment on the content of the story rather than the meaning of the words. Shared book reading is also considered an effective practice to enhance language and literacy development among both L1 and L2 children (Brand \& 
Donate, 2001); (Lonigan \& Shanahan, 2010). In other words, shared reading using big books are not only able to make the students actively participate in English class, but they also develop the students' literacy.

\section{METHOD}

This research was conducted in SDN Pejagan 1 in Bangkalan regency, East Java. The subjects of the research were 38 students in the fifth grade. This class was chosen since this class, based on the English teacher's opinion, is the nosiest but it has the lowest frequency of active participation during the English lesson. To solve this problem, a classroom research design was used which consisted of two cycles in which each cycle consisted of four steps; planning, acting, observing, and reflecting. Each cycle was conducted in 8 meetings in which per meeting was $1 \times 40$ minutes.

In the planning step, the big book and research instruments such as observation forms, interview guides, and questionnaires were prepared. The criteria of active participation were adopted from (Sayadi, 2007) definition of students' participation. The students who did one of the criteria mentioned were considered actively participated and given a tally score in the observation form. The big books were handmade with the size of the books was $40 \times 60 \mathrm{~cm}$ and $60 \times 80 \mathrm{~cm}$. The first big book entitled "My Family, a story written by the researcher while the second one used an authentic story "the very hungry caterpillar", which was written by Eric Carle. Besides the big book, observation forms, interview guides, and questionnaires were also prepared. In the acting step, the researcher taught English using big books. In warm-up activity, she introduced the vocabulary related to the big books using song or exercise. Then in the main activity, she used shared reading techniques using the big book. While reading, she frequently asked the students to check their understanding towards the content of the book or gave them opportunities to ask. Then in the follow-up activities, she asked the students to re-read the books, doing games, or giving puzzles. To make the observer easy to identify the students who actively participated, the researcher asked them to raise their hands.

The data was obtained by using an observation form, questionnaire, and interview guide. Observations were done when the acting phase was implemented. The data gained from observation was reported in a table which indicated the frequency of participation and the number of participants for each meeting. Then, the table is analyzed descriptively.

\section{RESULTS AND DISCUSSION}

\section{Results}

\section{Cycle 1}

In the first cycle, a big book entitled "My family" was used. The size of the book was $40 \times 60 \mathrm{~cm}$. To keep the big book in its place, the researcher used an easel of the plywood. The researcher acted as the teacher while the English teacher sat on the back row to 
observe the students' participation. The observation started at the second meeting since the first meeting was used for the introduction. Both the English teacher and researcher agreed that the choral answer was not considered as active participation since it would be difficult to be recorded. The researcher then told the students if they wanted to answer the question or to ask something, they had to raise their hands.

The students were happy when the researcher used the big book in teaching English since it was their first time to see such a big storybook. Most of them even move closer to the big book to see the book clearly. While reading, the researcher paused to ask some genuine questions, such as "How many sisters and brothers do you have at home? What are your father and mother? Do you stay with your grandma and grandpa?" These questions made the students participate actively in the shared reading. They sometimes forgot to raise their hand tough the researcher told them frequently to do so. The students frequently answered the questions bilingually. However, the researcher always gave the instructions and questions in simple English to make them used to the target language.

Since the students got easily bored, the researcher combined the shared reading using the big book with other activities such as doing a puzzle or guessing game related to the content of the big book. The students were enthusiastic to do the activities in pairs or groups. Until the last meeting of the first cycle, only five out of thirty-eight students who never participated at all even for answering or re-reading the big book. It could be concluded that the students' active participation had improved than before the big book was used. However, the result was still not satisfying since the number of students' participation tended to decrease from one meeting to another meeting. Since the research was conducted in August, most students participated in some competitions to celebrate Indonesian Independence day. Therefore, they looked tired when they came to class. To make them relaxed, the researcher asked them to sing a song related to the content of the big book, "one and one". It was successful to make them relaxed and happy to learn again. Therefore, based on the result of observation and questions are given at the end of cycle 1 , the reflecting was done and the result was used to plan the second cycle.

The frequency of the students' participation can be seen in the following chart.

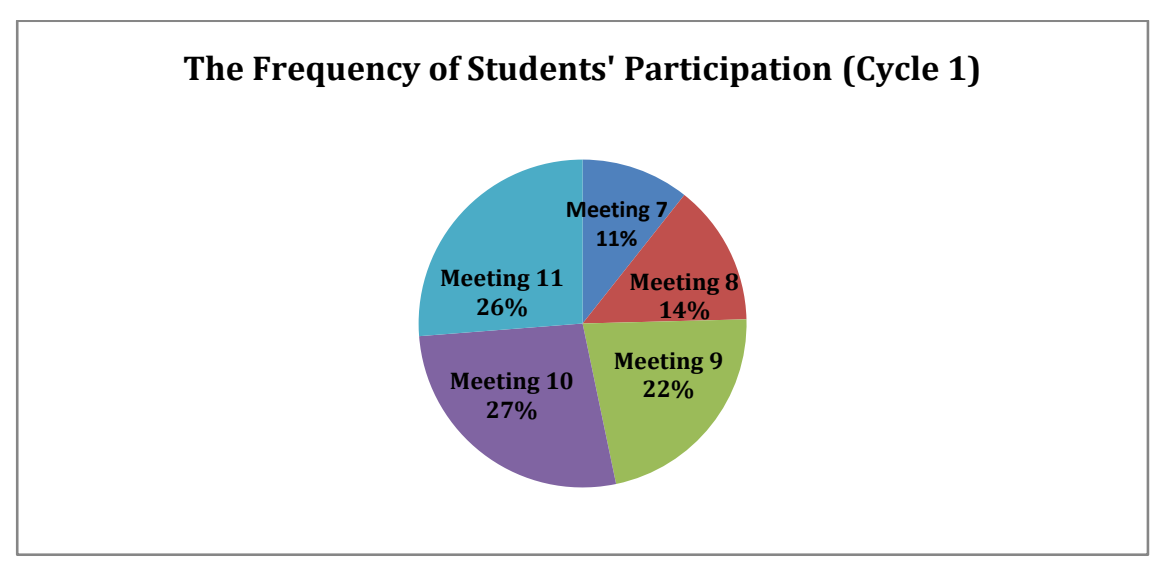

Chart 1. the frequency of students' participation (Cycle 1) 


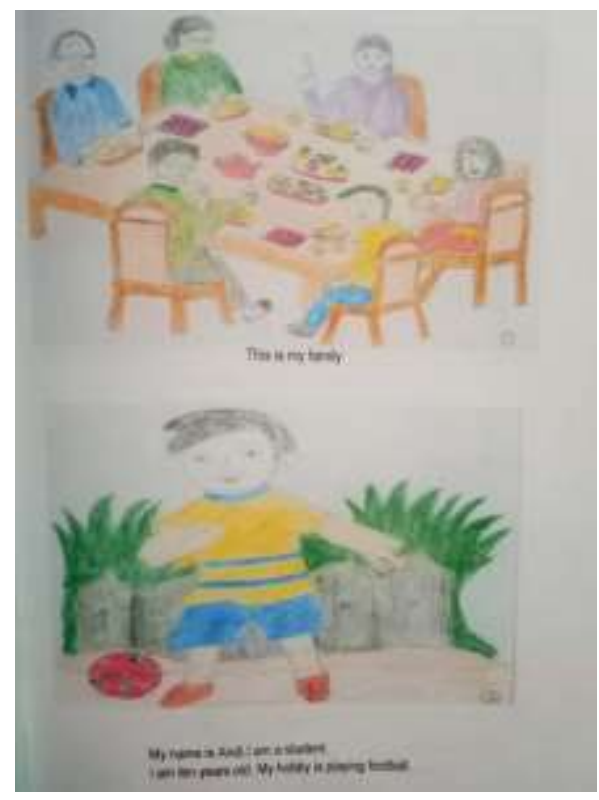

Fig 1. The first big book, "My Family"

Based on the result of reflecting in cycle 1 (See Chart 1 and Picture 1), it revealed that the size of the big book was not big enough for 38 students. The students in the back row couldn't see the book clearly. Moreover, the color and the story of the big book in cycle 1 were not interesting. The researcher used colored pencils and her own story. Therefore, in cycle 2, the big book was enlarged into 60 x80 cm. The adapted story entitled "the very hungry caterpillar" by Eric Carle was used. In this story, the hungry caterpillar was named Upik, could eat much fruit and food. Not only about the name of fruit and food, in this story, were the students also indirectly taught about the name of the day. To make the big book more interesting and eye-catching, the paint was used to color the big book instead of colored pencils.

\section{Cycle 2}

In cycle 2, the researcher still used the same steps of using big book. She read the big book first and invited the students to answer her question while reading the big book. Then she asked the students to re-read the big book together. In cycle 2 , the students were more curious and actively participated. They were amazed by the character of Upik, the caterpillar who could eat much fruit and food. One of the students even asked the researcher about that,

Student 1: "Miss, Why Upik eat terus?" (Miss, why did Upik continuously eating?

Researcher: "Who can answer Santi (not the real name)?"

Some students raised their hands.

Researcher: "Yes, Reza (not the real name), please answer Santi's question!"

Student 2: "Because Upik is hungry Miss"

Researcher: "Good answer, any other answer?" 
Student 3: "Because Upik mau berubah jadi butterfly Miss, jadi dia butuh many fruit and food" (Because Upik will change into butterfly Miss, so she needs much fruit and food to eat).

Researcher: "Very Good Dini (not the real name). Upik needs to eat much because she will be a butterfly"

Many new words in the second big books were introduced to the students. However, when they asked the researcher about the meaning, she used the picture in the big book to answer their questions. For example, when one of the students asked the meaning of "cocoon", instead of answering the question, she pointed out the picture and told the students that it was a cocoon. The students then could understand that cocoon means kepompong in Indonesian. Another fact also occurred in this cycle. One of the students raised his hand and told the researcher that there was a misspelling on page four. On that page, it was written "he", while Upik is a female, so it should have been written, "she". The researcher thanked the student and appraised his bravery. Another student also stated her disagreement about the greedy characteristic of Upik. She said that it was impossible for the real caterpillar to eat that much. The researcher explained that the story was not a real story. In reality, the caterpillar only ate leaves for a living.

From the observation form, the frequency and kinds of participation improved significantly. All the students participated and they didn't only answer the researcher questions but also asked, discussed, and performed. At the end of cycle 2, the researcher distributed the questionnaire which asked the students' opinions about the use of the two big books.

The frequency of students' participations in Cycle 2 as well as the percentages of each meeting can be seen in the Cycle 2 .

\section{The Frequency of Students' Participation (Cycle 2)}

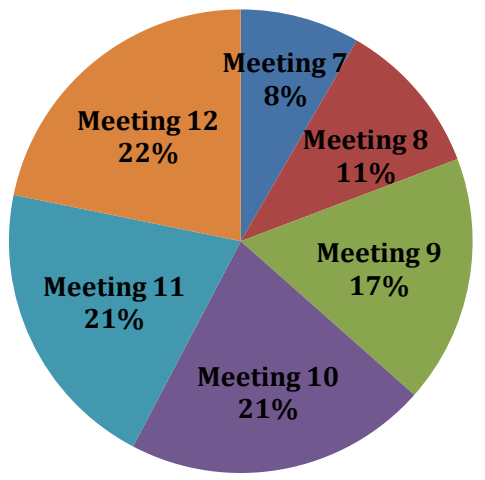

Chart 2. The Frequency of Students' Participation (Cycle 2) 


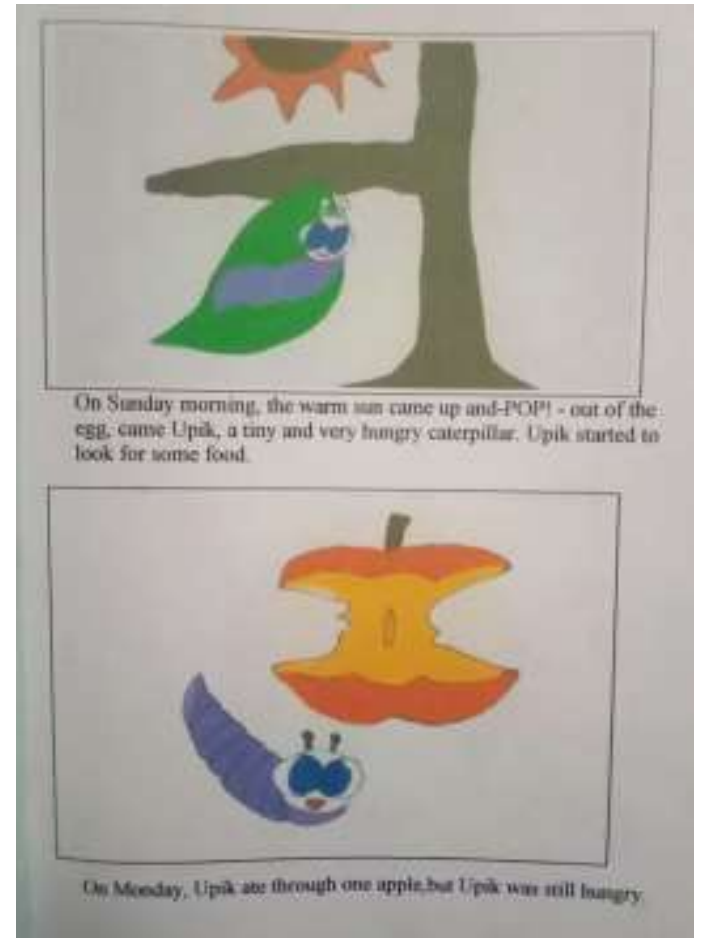

Fig. 2. The second big book, "Upik, A very Hungry Caterpillar"

\section{Discussion}

This research revealed that in cycle 1 , the students' active participation had improved compared to the teaching without using big book. Since it was the first time for them to see a big book in their English class, they were happy and eager to participate actively. When it juxtaposed with the findings from the previous study conducted by ( $\mathrm{S}$. Shilova, 2019) This study confirms that the most interesting part of the lesson for students in elementary school is when they learn something new and being engaged in the activity. Although they have a short span of attention, the shared reading using a big book that gave the students information in a small portion kept them focus on the lesson longer. As stated by E. M. Mahone \& Scheneider, (2013) that the information in the lesson should be given in small portions but in a way that will improve the children's distributed audiovisual attention.

Another fact revealed in cycle 1 was the number of participation from one meeting to another meeting in cycle 1 tended to decrease. It might due to some factors, such as the physical condition of the students and the appearance of the big book. As stated previously that the research was conducted in August, the month which was full of activities to celebrate Indonesian Independence day. It made them physically tired and sleepy when attended the English lesson which was delivered in the last period. As stated by Krashen in (Lightbown \& Spada, 2013), a learner who is tense, angry, anxious, tired, or bored may "filter out" input, making it unavailable for acquisition. Therefore, the researcher combined the shared reading using big book with other activities such as reciting English song and doing crossword puzzle since elementary school students enjoy socializing with 
others, and activities that work best with young learners are those in which they are working with others in pairs or groups, rather than remaining in their seats, listening to the teacher (Richards, 2019). These activities successfully helped to motivate the students to focus on the lesson again.

Another factor that made the number of students' participation decreased in cycle 1 was the appearance of the big book. The first big book was $40 \times 60 \mathrm{~cm}$ and told about the family. The size was too small for a class with 38 students. Moreover, the color and the content of the story according to the students were not too interesting. At first, they were enthusiastic about the big book since it was their first time using it. However, when it was used for the next meeting, the students' curiosity and interest declined. Therefore some improvements were done in cycle 2 .

In cycle 2, the researcher did some improvements dealing with the big book's appearance based on the result of reflecting in cycle 1. A bigger big book with eye-catching characters in and also an interesting story made the students' participation increased significantly and steadily from one meeting to another meeting, from 91 in cycle 1 to 156 participation. It again proved that the students were highly motivated to participate actively by the use of big book. As stated by (N.A. Rahim \& Harun, 2010) that bright, colorful illustrations of the big book would interest and motivate even less able students to respond in English. Their facial expressions and their positive comments when the second big book was used in shared reading were clear indicators of their interest. Moreover, the elementary school-age children are likely to pay more attention during those classes that remain coherent, meaningful, interesting, and practical (Brown \& Lee, 2015). In addition to the increasing number of participation, the distribution of the participants was also equal since all the students participated, not dominated by some students as in cycle 1 . The result of cycle 2 was in line with the findings of previous studies (Yacoob \& Pinter, 2008); (F. Fahmi, 2015) which state that big book can positively involve the students in the lesson.

In a nutshell, this study concludes that big books as instructional media in shared reading techniques are effective and applicable to encourage elementary school students to participate actively in English classes.

\section{CONCLUSION}

Based on the research findings and discussion, it can be concluded that the big books can encourage elementary school students to participate actively in English classes. The indications of their active participation are: (1) the students get involved in the activities which need their participations such as asking and answering questions, doing exercises related to the big books, doing games, and re-reading the big books for their friends, (2) the students who never participated before the research was conducted were willing to participate during the big books were used in the research, (3) the distribution 
of the participation was fair since all students got chance to participate. There was no domination of some students like what happened before the research was conducted, (4) the students' participation came from the students' own initiative since the researcher never asked any certain students to participate unless they raised their hands.

Using big books in English class created a non-threatening situation which triggered the students to express their opinion, feeling, and disagreement freely. By enlarging the big book, using brighter color for the pictures in it, using interesting characteristics and stories in the big book, the students' participation could be maintained. Big books successfully stimulated students to recall and use their previous knowledge. It was proved when there were mistakes in the big books; the students confirmed them to the researcher and corrected the mistakes themselves.

\section{RECOMMENDATION}

The use of big books as media in teaching English at the elementary school level should be accompanied by the use of other techniques such as songs, games, or fun exercises so the students will not get bored. To be successful in using big books, the English teacher's ability in delivering them as interesting as possible is crucially needed. Therefore, for further research, it can be a focus on kinds of interactions between the teacher and students, or students and students during the use of big books.

\section{REFERENCES}

Abdullah, Mohd. Y., Bakar, N. R. A., \& Mahbob, M. H. (2012). Student's Participation in Classroom:What Motivates them to Speak up? Procedia - Social and Behavioral Sciences, 51, 516-522. doi: 10.1016/j.sbspro.2012.08.199.

Brand, T. S., \& Donate, M. J. (2001). Storytelling in Emergent Literacy. New York: Delmar Thomson Learning.

Brown, H. D., \& Lee, H. (2015). Teaching by Principles (4th edition): An Interactive Approach to Language Pedagogy. London: Pearson Education.

Cameron, L. (2001). Teaching English to Young Learners. Edinburgh: Cambridge University Press.

Fahmi, D. I., Suhartono, L., \& Arifin, Z. (2015). Improving Students' Reading Comprehension using Big Book. Jurnal Pendidikan dan Pembelajaran Khatulistiwa, $4(1), 1-11$.

Hall, S. C., \& O'Connor, B. (2006). Using Big Books: A Standards-Based Instructional Approach for Foreign Language Teacher Candidates in a PreK-12 Program. Foreign Language Annals, 39(3), 487-506. doi: 10.1111\%2Fj.1944-9720.2006.tb02901.x.

Indrasari, A., Novita, D., \& Megawati, D. (2018). Big Book: Attractive Media for Teaching Vocabulary to Lower Class of Young Learners. 3(2), 141-154.

Lightbown, P. M., \& Spada, N. (2013). How Languages are Learned (4th edition). Oxford: Oxford University Press. 
Lonigan, L., \& Shanahan, S. (2010). The National Early Literacy Panel: A Summary of the Process and the Report. 39(4). 279-285. doi: 10.2307/27764597.

Mahbob, M. H. (2012). Student's Participation in Classroom:What Motivates them to Speak up? 51, 516-522. doi: 10.1016/j.sbspro.2012.08.199.

Mahone, E., \& Schneider, H. (2012). Assessment of Attention in Preschoolers. Neuropsychology Review, 22(4). 361-383. doi: 10.1007/s11065-012-9217-y.

Mustapha, S. M., Rahman, N. S., \& Yunus, M. M. (2010). Factors Influencing Classroom Participation: A Case Study of Malaysian Undergraduate Student, Asian Journal of Education and Social Study. 9. 1079-1084. doi: 10.9734/ajess/2019/v4i330118.

Rahim, N. A., \& Harun, N. I. (2010). Students' Perception Towards the Usage of the Big Book. Gading Business and Management Journal', 14, 47-54.

Sayadi, Z. A. B. (2007). An Investigation into First Year Engineering Students' Oral Classroom Participation: A Case Study (Unpublished degree dissertation, Universiti Teknologi Malaysia). Universiti Teknologi Malaysia, Malaysia.

Shanahan, T., \& Lonigan, C. J. (2010). The National Early Literacy Panel: A Summary of the Process and the Report. Educational Researcher, 39(4), 279-285. JSTOR. doi: $10.2307 / 27764597$.

Shilova, L., Masterskikh, S., Mensh, E., \& Zemlyanova, M. (2019). Learning English language in primary school: Motivational Factors and Their Role in Management Strategies. International Journal of Educational Management, 3. doi: 10.1108/IJEM-03-20190115.

Wijayanti, L. P. A., Padmadewi, N. N., \& Mahayanti, N. W. S. (2017). The Effect of Big Book as Media On Students' Reading Comprehension at Fifth Grade of Elementary School in SD Laboratorium Undiksha Singaraja. International Journal of Language and Literature. 1(3), 142-148. doi: 10.23887/ijll.v1i3.12544.

Yacoob, A., \& Pinter, A. (2008). Exploring the Effectiveness of Using Big Books in Teaching Primary English in Malaysian Classrooms. Malaysian Journal of Learning and Instruction. $\quad 5, \quad 1-20 . \quad$ Retrieved from http://ejournal.uum.edu.my/index.php/mjli/article/view/7594). 
Elly Rosalina Susanti, Using Big Books to Promote the Elementary School ... 